\title{
Antecedents of Employee Intention to Stay: A Study of Employees in Zimbabwean SMEs
}

\author{
Elizabeth Chinomona \\ Department of Logistics, Vaal University of Technology, South Africa \\ chakubvaelizabeth@gmail.com
}

\begin{abstract}
Most research conducted on the influence of employee perception of equity (EPE), organisational citizenship behaviour (OCB), organisational commitment (OC) and turnover intention (ITS) has been on large organisations and little attention has been paid to SMEs. Studies on EPE and OCB have not filtered down to SMEs in developing countries. The primary objective of the study is to investigate the influence of OCB, EPE and OC on ITS in Zimbabwe's SME sector. It also sought to ascertain the kind of relationships between OCB and OC, EPE with OC, OCB with ITS, EPE with ITS and finally OC with ITS. Structured questionnaires were distributed to SMEs in five major cities. A quantitative method using Smart PLS was employed to test the relationships among the three hypotheses. The results showed that there is a positive relationship between the three proposed hypotheses. Based on the findings, recommendations will be made to both the government policy makers and SME owners. The proposed study is expected to have practical and theoretical implications to both the policy makers in the government and the owners of small businesses in Zimbabwe. In addition, it will provide added insights and new knowledge to the existing body of literature on human resource management, hitherto not studied extensively in developing countries of Southern Africa and Zimbabwe in particular.
\end{abstract}

Keywords: Equity theory, SMEs, Organisational citizenship behaviour, Employee perception of equity, Organisational commitment,

\section{Introduction}

Background of the study: The main objective of the study is to investigate the influence of organisational citizenship behaviour (OCB), employee perception of equity (EPE) and organisational commitment (OC) on employee intention to stay (ITS) in Zimbabwe's SME sector. SMEs are the mainstay of economies and societies of many countries around the world. Over the years, research has shown that these enterprises are critical to the economy because of the way in which they contribute to the gross domestic product (GDP) and their ability to provide goods and services, which large enterprises depend upon (Kapoor, Mugwara \& Chidavaenzi, 1997; Machipisa, 1998; Nyoni, 2002; Chipika \& Wilson, 2006). In many countries, SMEs play a significant role in local communities by providing employment opportunities, social stability and economic welfare (Biggs \& Shah, 2006). Research on OCB and equity concerns has developed as a worthwhile body of systematic investigation during the past twenty years (Yoon \& Sur, 2003; Ravichandran \& Gilmore, 2007; Park, Ellis, Kim \& Prideaux, 2010; Nicklin, Greenbaum, McNall, Folger \& Williams, 2011). Researchers have debated extensively that $\mathrm{OCB}$ is an endemic phenomenon in organisations and that it deserves more consideration and practical scrutiny (Cho \& Johanson, 2008; Podsakoff, Whiting, Podsakoff \& Blume, 2009). The importance of OCB lies in its prospective positive consequences and effects on work results. Research has provided substantial proof that OCB, among others, breeds positive perceptions of equity, enhances OC and finally prompts employee ITS in the organisation (Ferris, Adams, Kolodinsky, Hochwarter \& Ammeter, 2002; Rosen, Chang, Johnson \& Levy, 2009; Park et al., 2010).

On the other hand, the known wisdom in the human resource management literature is that most labour disputes emanate from workers' perception of inequity (Nicklin et al., 2011). This is because perceived inequity can affect attitudes and behaviours in a variety of ways, which eventually precipitates labour disputes or even strikes (Colquitt, Conlon, Wesson, Porter \& Ng, 2001). It is argued further in the literature that perceived inequities at the work place also negatively impact on job performance, cooperation with coworkers, work quality and commitment to employers (Cropanzano, Howes, Grandey \& Toth, 1997). Notable in the literature is the fact that when workers' commitment to their organisation is lacking, turnover intention or turnover is prevalent (Gono, 2009, Chinomona \& Dhurup, 2016). Moreover, it is argued in the extant literature that turnover intention or turnover should be reduced or shunned by organisations since it is more costly to replace an employee than to retain one (Carson \& Gilmore, 2000). In view of that, research interests on the effects of OCB, perception of equity and OC on employee ITS are substantial and growing 
(Andrews, Witt \& Kacmar, 2003). Regrettably, the majority of the research has concentrated on large firms, with little concern to the small and medium enterprise (SME) sector in developing countries of Africa.

Problem Statement: According to Chinomona, Lin, Wang and Cheng (2010:110), "the SME sector in both developed and developing countries is considered the engine of economic growth and a vehicle for employment generation". However, it is surprising that the impact of OCB, EPE and OC on employee ITS in the SME sector has been largely neglected by researchers. Indeed, such an inquiry is imperative and is likely to contribute to a deeper understanding of the relationship between these constructs. Notably, there is growing evidence indicating that large firms and SMEs characteristics are different (Sieger, Bernard \& Frey, 2011). Thus, it can be expected that the findings from large firms and SMEs might be different. This necessitates an empirical confirmation or disconfirmation of previous findings in the context of SMEs, hence the need for this study. Equally alarming is the fact that a plethora of such studies on large firms was based on developed countries (Chinomona \& Pretorius, 2011:170, Chinomona \& Dhurup, 2015). "It has been argued in previous research from developing countries that it is naive and not judicious to assume a-priori that findings from developed countries apply in developing countries such as those in Southern Africa" (Chinomona et al., 2010:111; Chinomona, 2012; Chinomona, 2016). The effects of OCB, perception of equity and OC on employee ITS in the context of SMEs in Zimbabwe is long outstanding and imperatively warrants further academic and in-depth scrutiny.

\section{Literature Review}

Social Identity Theory (SIT): Social identity theory (SIT) has been used in this study to explain the relationships between OCB, EPE, OC and ITS in Zimbabwean SMEs. This is because social identification leads to loyalty, belongingness, support for the organisation and ultimately ITS. SIT leads to outcomes that are traditionally associated with group formation and reinforces the antecedents of identification. Organisational identification has long been recognised as a critical construct in the literature of organisational behaviour affecting both the satisfaction of the individual and the effectiveness of the organisation (Ashforth \& Mael, 1989). In this regard, social identities often are developed through social interactions (Li, Xin \& Pittutla, 2002), therefore, can be used to explain commitment in organisations. According to SIT, people tend to classify themselves and others into various social categories. These categories include organisational membership, religious affiliation, gender and age cohort. Ashforth and Mael (1989:20) define social identification as a "perception of oneness with a group of persons". This stems from the categorisation of individuals, the distinctiveness and prestige of the group, the salience of out groups and the factors associated with group formation. This leads to activities that are congruent with the identity, support for institutions that embody the identity, stereotypical perceptions of self and others and outcomes that traditionally are associated with group formation (Ashforth \& Mael, 1989). According to SIT, an individual does not have a single personal identity, but multiple social identities (Tajfel \& Turner, 1979; Terry, Hogg \& White, 1999; Hogg \& Vaughn, 2002). One's social identity is formed as an individual places oneself into distinct social categories based on similarities with these groups, such as students, Christians, or females (Scott, 2007). It is also through this process that individuals develop their organisational identities, a specific type of social identity through comparing themselves with others in their organisations and reflecting on these comparisons over time.

Relating SIT to the current research context, this study submits that, for instance, workers in SMEs can develop organisational identities to their current organisation based upon their comparisons of their SME and other SMEs (Carmon et al., 2010). This implies that when employees find their group identity with an SME to be important to them, an attempt is made to distinguish themselves from other SMEs (Abrams, Hogg, Hinkle \& Otten 2005). Thus, a group of employees belonging to one SME may feel more attached to their SME, hence their overall organisational identity (Hogg, Abrahams, Otten \& Hinkle, 2004). It, therefore, is submitted in this study that the more favourable the comparisons of an organisation an employee perceives of his or her SME or the more distinct it is from other SMEs, the stronger the expected foundation of a positive social identity. It is anticipated also that stronger organisational identity in SMEs is forged when individual employees perceive their values to match that of the organisation. In this case, workplace interactions and organisational value congruence fosters organisational identity in the SMEs context (Pratt 1998). However, when an employee does not identify with an organisation, it can lead to distrusting organisational 
information or to interpretation of information in a way that reinforces feelings of disidentification (Dukerich, Kramer \& Parks, 1998:245).

"Organisational identification, therefore, seems to be a specific type of social identification that elicits perceptions of shared values, belonging and loyalty to an organisation" (Cheney, 1982:33). This sense of commitment in SMEs is based partially on an obligation to continue employment with an organisation and the perception that staying with an organisation is the right thing to do (Meyer \& Allen, 1991; Fields, 2002). As organisational identification increases, it positively influences a variety of work attitudes, behaviours and outcomes. Organisational identification is linked theoretically and empirically to motivation, decision making, employee interaction and length of service (Cheney, 1983); turnover and turnover intentions (Mael \& Ashforth, 1992; Van Dick, Christ, Stellmacher, Wagner, Ahlswede \& Grubba, 2004) and job satisfaction and performance (Carmeli, Gilat \& Waldman 2007). Organisational identification plays an important role in employees' well-being, satisfaction and productivity (Gautam, van Dick \& Wagner, 2004), therefore, has promising potential for increasing OC (Scott et al., 2007; Van Dick et al., 2004). Becker (1992) noted that one of the primary goal for commitment to an organisation is identifying with the organisation. Individuals who embrace their organisation's goals and missions through identification processes are more likely to remain committed and stay in the organisation than individuals who do not (Van Dick et al., 2004:354).Therefore, if an employee begins to identify with an organisation, particularly if they perceive they are a member of the ingroup then it is likely they will also begin to feel more committed to the organisation and stay within the organisation. Social identification ultimately results in good OCB, equity in the organisations and loyalty to the organisation, resulting in employees remaining with the organisation.

Organisational Citizenship Behaviour: Kinicki and Kreitner (2008:165) define OCB as "behaviours consisting of employee behaviours that are beyond the call of duty. Examples include gestures as constructive statements about the department or organisation, expression of personal interest in the work of others, suggestions for improvement, care for organisational property, training new people, punctuality and attendance well beyond standards or enforceable levels". OCB positively correlates with customer satisfaction, OC and performance ratings (Bateman \& Organ, 1983). There is a broader impact of OCBs on organisational effectiveness (Bolino \& Turnley, 2005). It is important to note that when employees are being treated fairly at work, they are more willing to engage in OCB and managers are encouraged to make and implement employee-related decisions in an equitable fashion (Chiang \& Hsieh, 2011, Chinomona \& Dhurup, 2016). Therefore, SME employees' citizenship behaviour refers to that behavioural motivation that goes beyond the normal call of duty through cooperation among colleagues, self-improvement and creating a positive organisational image (Cho \& Johanson, 2008). The extant organisational behaviour literature indicates that such innovative and spontaneous behaviour by employees can contribute greatly to the cooperation and performance of an organisation (Stamper \& Van Dyne 2003). Different dimensions are used to measure and evaluate OCB. Chiang and Hsieh (2012:374) used five dimensions to evaluate OCB, namely altruism, conscientiousness, sportsmanship, courtesy and civic virtue. William and Anderson (1991:600), on the other hand, categorise OCB into two dimensions, namely OCB of individuals and OCB toward organisations. Podsakoff, Ahearne and MacKenzie (1997:262) propose three dimensions of OCB, namely helping behaviour, sportsmanship and civic virtue. Van Dyne and LePine (1998:108) categorise OCB into two dimensions, namely helping behaviour and voice behaviour. However, Podsakoff et al. (2009:122) points out that although researchers use different evaluative dimensions, the most common measurement methods are the five dimensions, which were first proposed by Organ (1988:3 \& 1990:43). These dimensions are altruism, conscientiousness, sportsmanship, courtesy and civic virtue.

Employee Perception of Equity: Scholars and practitioners have progressively recognised the relevance of equity as a determinant of organisational efficiency and effectiveness (Greenberg, 2009; De Cremer, Van Dijke \& Mayer, 2010; Van Dijke, De Cremer, Mayer \& Quaquebeke, 2012). Plato and Socrates are being recognised as the gurus on justice or fairness. The scholarship on justice and fairness has been a topic of philosophical interest that extends back at least as far as Plato and Socrates (Colquitt, Colon, Wesson, Porter \& Ng, 2001). The existing spate of literature consistently finds that people care about fair treatment and when individuals perceive that they are treated fairly, they express greater satisfaction with social relationships (Kanopaske \& Werner, 2002; Almar, 2005; Parket al., 2010; Nicklin et al., 2011; Robbins \& Judge, 2011). Kinicki and Kreitner (2008:163) define equity as the perception of being treated fairly at the work place. Equity is also defined as 
"fairness, rightness, or deservingness in comparison to other entities, whether real or imaginary, individual or collective, person or non-person" (Kwon \& Jang, 2012:1236). Accordingly, EPE are premised on their expectations that the proportion between efforts spent and rewards received at work should be justifiable. As a phenomenon, employees always anticipate fair treatment at the workplace and respond in a certain way if they perceive unfairness. Unfairness results in labour disputes, strikes and high turnover ratio (CohenCharash \& Spector, 2001; Colquitt, Conlon, Wesson, Porter \& Ng, 2001). It is further argued that perceived inequities at the work place also impacts negatively on job performance (Park et al., 2010), cooperation with co-workers (Kanopaske \& Werner, 2002), work quality (Cardy, Miller \& Ellis, 2007; Tufail et al., 2016) and commitment to employers (Balsam \& Miharjo, 2007). Research studies have also confirmed that it is more costly for firms to recruit a new worker than to retain an existing one (Almar, 2005; Balsam \& Miharjo 2007; Park et al., 2010). For example, employees will work as hard as other workers will or will not think of quitting the job if they are given an equal reward. Cater and Zabka (2009) postulated that treatment by an organisation would be felt as fair when it is appropriate according to the employee's perceptions, expectations and attitudes. Thus, when workers perceive the ratio to be equal to that of others then a state of equity is said to exist and this will consequently result in OC. However, if the proportion is unequal then the employees experience equity strain. Consequently, when workers see themselves as under rewarded, the resultant tension creates wrath (Janssen, 2001). Inequity contributes to negative consequences within the organisation and equity results in smooth running and functioning of the organisation (Park et al., 2010). Kanopaske and Werner (2002:406) identify three types of equity, namely external, internal and employee.

Organisational Commitment: Researchers from either a psychological perspective or sociological thrust have also defined OC. For example, those who subscribe to the psychological view submit that OC acts as a psychological bond to the organisation and influences individuals to act in ways that are consistent with the interests of the organisation. These researchers suggest that low levels of OC may be dysfunctional to both the organisation and the individual, while high levels may have positive effects that lead to higher performance, greater satisfaction and low turnover. Another school of thought has differentiated OC definitions according to how the construct has been conceptualised by organisational behaviour researchers and social psychologists (Razali, 2004:465). For instance, organisational behaviour researchers use the term to describe the process by which employees come to identify with the goals and values of the organisation and desire to maintain membership of the organisation. On the other hand, social psychologists have focused on behavioural commitment. This approach draws heavily on the works of several social psychologists and focuses on how an individual's past behaviour serves to bind the organisation. However, despite all the other definitions, this paper will define $O C$ as an employee's strong beliefs in the organisation's goals and values, a willingness to work on behalf of the organisation and a desire to maintain membership in the organisation (Porter et al., 1974:604). This sense of commitment among employees could be used not only to preserve the longevity of their businesses, but also to create a positive working environment for employees (Yamaguchi, 2013). Scholars have discovered three components involved in OC, which are affective or emotional commitment, continuance or calculative or instrumental commitment and normative or moral commitment (Allen \& Meyer, 1990; Meyer \& Allen, 1997; Jones \& Mclntosh, 2010).

Intention to Stay in an Organisation: Many questions have been asked concerning ITS. Why do SMEs employees in Zimbabwe opt to stay at a company or to leave? What makes SME employees contemplate leaving an organisation? How can employers recruit valued SME employees who will stay longer in an organisation? These questions have been asked for decades as employers face a decreasing pool of talent to meet increasing business needs. The turnover rate is one of the most persistent challenges faced by organisations (Joseph, Kok-Yee, Koh \& Ang, 2007). In some cases SME employees would prefer working for the SME no matter what, to show respect and loyalty. Turnover has negative and positive outcomes in an organisation. The negative outcomes are more obvious, such as direct recruiting and training costs as well as indirect costs due to disruptions in organisational processes (Thatcher, Stepina \& Boyle, 2003; Thatcher, Liu, Stepina, Goodman \& Treadway, 2006).The cost of hiring new employees, lower work quality by new employees and putting a company's reputation at stake are among the other negative consequences of SME personnel leaving a workplace. Furthermore, turnover has the potential to lead organisations to lose individuals with relevant and valuable work experience, as well as their tacit knowledge about how internal systems operate (McKnight, Phillips \& Hardgrave, 2008). Brown (2000) suggests that SME hiring costs, lost salaries, training investments, benefits and tax payments could cost a company US $\$ 100,000$ per senior SME 
employee who quits the organisation within 180 days of joining. Because of high rates of turnover and associated costs, employers have shifted from perceiving SME employees as a replaceable commodity to considering them as valued and essential assets (Thatcher et al., 2003:233). The paybacks of SME turnover, on the other hand, are less well understood. Replacement workers often are paid lower salaries than those that they replace. Recruiting new blood results in the infusion of new knowledge, ideas and experience into the company and enhanced opportunities for promoting those who stay (Ghapanchi \& Aurum, 2011; Ucho et al., 2012). Overall, SME turnover costs organisations money. Although some turnover is unpreventable, such as employees leaving for medical reasons, many other reasons for leaving a job generally are considered avoidable. Hence, it is important for company management to understand what factors influence SME employee turnover in order to control turnover in their organisations.

The proposed research model: Drawing from the literature review, in particular the theoretical and empirical literature aforementioned, a research model is conceptualised. Hypothesised relationships between research constructs are developed thereafter. In the conceptualised research model, OCB and EPE are proposed to be the predictors of OC and employee intentions to stay. Employee ITS will be the outcome variable while $\mathrm{OC}$ is posited to be a mediating variable. Furthermore, the model proposed has one-directional causal effect, in other words it is a recursive model. OCB and EPE serve as exogenous latent factors and OCB and ITS as endogenous latent factors. Figure 1.1 illustrates this conceptual research model.

Figure 1: The research model

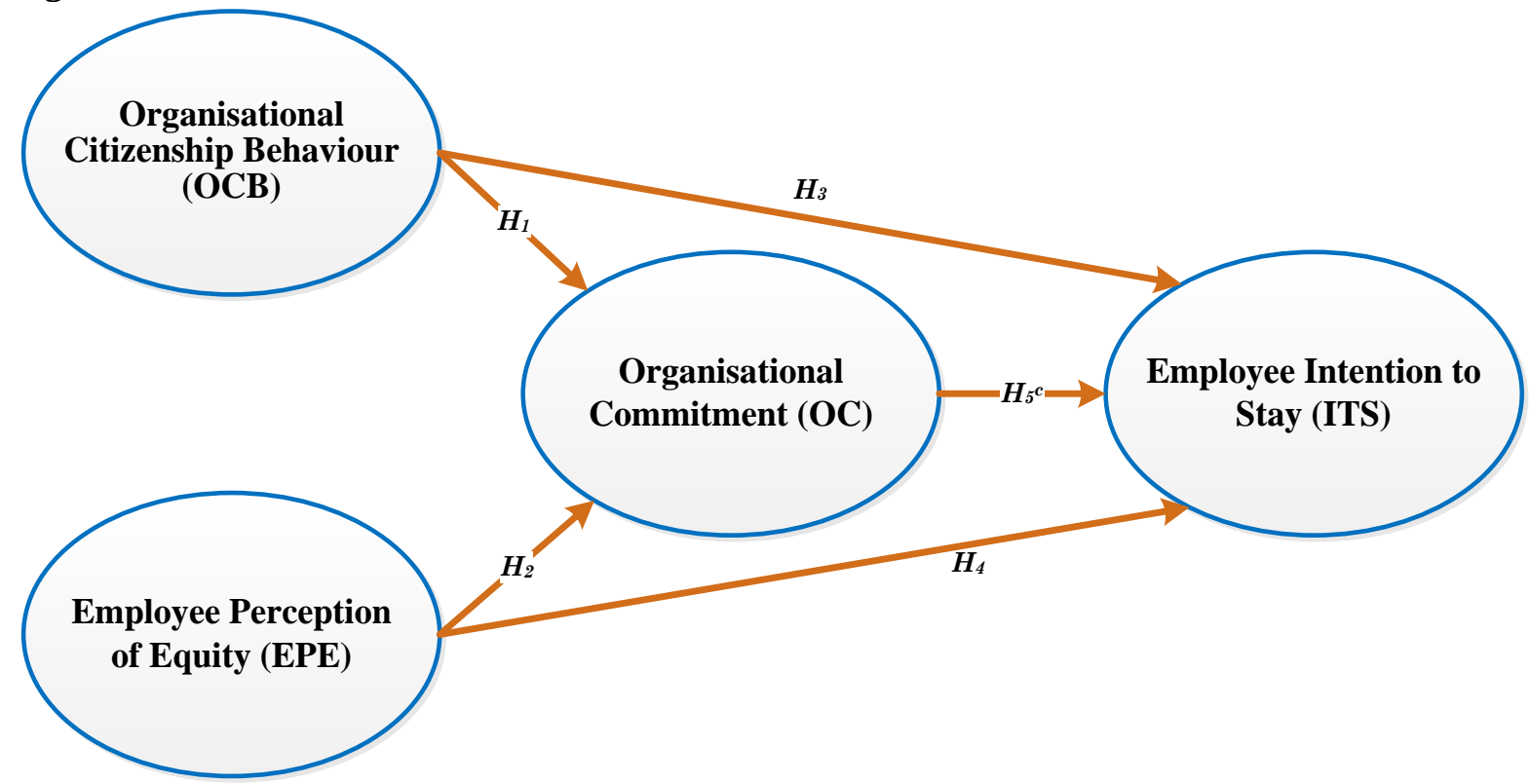

Hypotheses:

Relationship between organisational citizenship behaviour and organisational commitment: Bolino and Turnley (2005) acknowledge that there is a wider effect of OCBs on organisational effectiveness, which leads to $\mathrm{OC}$ at workplaces. It is important to note that when employees perceive to be treated fairly at work they are more willing to engage in OCBs, therefore, managers are encouraged to make and implement employee-related decisions in an equitable fashion (Chiang \& Hsieh, 2011:181). Successful organisations need employees who will do more than their usual job duties, who will provide performance beyond expectations. Employees who engage in "good citizenship" behaviours help others on their team, volunteer for extra work, avoid unnecessary conflicts, respect the spirit as well as the letter of rules and regulations and gracefully tolerate additional work (Cho \& Johanson, 2008:307). Empirical evidence from the organisational behaviour literature indicates that organisations that have employees with good citizenship behaviour outperform those that do not have such employees (Greenberg, 2009; Jain \& Cooper, 2012; Jung \& Yoon, 2012). In the same vein, good OCBs are reported in extant literature to precipitate reduced workplace absenteeism, turnover intention and deviant workplace behaviour (Bolino \& Trurnley, 2005). According to Jung and Yoon (2012), organisational behaviours such as reduced workplace absenteeism, turnover 
intentions and deviant workplace behaviour are associated with OC. Jain and Cooper (2012) echoed the same sentiments and found that OCB leads to OC. Because of OCBs, SME employees who bring their entire selves (physical, mental, emotional and spiritual) to the company, regard their work as a mission and more than as a mere job (Jain \& Cooper, 2012). Eventually, this in turn will likely equip them with the enthusiasm to pursue extra citizenship behaviours at work (Moxley, 2000). Thus, an association between SME employees' citizenship behaviour and their OC can be conjectured. Previous studies have also provided support for the positive influence of OCB and OC (Milliman, Czaplewski \& Ferguson, 2003). Accordingly, it is expected in this study that employee organisational behaviours are likely to lead to OC in the SME sector in Zimbabwe. Therefore, drawing from this deliberation, $\mathrm{H} 1$ is proposed as follows:

H1: Organisational citizenship behaviours have a significant strong positive effect on their organisational commitment in the Zimbabwe SME sector.

Relationship between employee perception of equity and organisational commitment: Employees are likely to develop a strong positive view towards their organisation if they perceive fairness at the workplace. Such a strong positive attitude is likely to arouse employees' emotional attachment to their organisation. Consequently, the stronger the perceived fairness, the stronger the positive attitude and emotional attachment the employee has to the organisation, hence the stronger OC. It is believed that when workers put effort into their workplace and that effort is fairly rewarded, commitment to that organisation will result (Mowaday, Porter \& Steers, 1979; Almar, 2005). Such employee perception of fair play is likely to motivate and induce them to be loyal to that organisation and eventually lead to long-term OC. The equity theory has been used in numerous human resources studies to substantiate this reasoning (Kotabe, Dubinsky \& Chae, 1992; Shelley, 2001). On top of this, prior empirical studies have supported a positive linkage between EPE and OC (Laschinger, Shamian \& Thomson, 2001; Lemons \& Jones, 2001; N'Goala, 2007). Likewise, when SME employees perceive their rewards to be fair or equitable when compared to their effort they are likely to be committed to that organisation. Therefore, based on the aforementioned theoretical reasoning and empirical evidence, it is posited that:

H2: Employees' perceptions of equity have a significant strong positive effect on their organisational in the Zimbabwe SME sector.

Relationship between organisational citizenship behaviour and employee intention to stay: The questions that challenge academics and human resource practitioners alike are: Why do people leave their jobs? Why do they stay in their jobs? Over the years, researchers have developed partial answers to these questions (Mitchell, Holtom, Lee, Sablynski \& Erez, 2001). Perhaps, given alternatives, people stay if they are satisfied with their jobs and committed to their organisations and leave if they are not. However, empirical evidence indicates that work attitudes play a relatively small role in employee tenure or turnover intention (Hom \& Griffeth, 1995; Griffeth, Hom \& Gaertner, 2000). On the other hand, empirical evidence entails that employees with OCB always feel wanted and act as part of the organisation and will opt for staying on the job (Mitchell et al., 2001:1102). The extant organisational behaviour literature indicates that, such innovative and spontaneous behaviours by employees can greatly contribute to the cooperation and performance of an organisation and ultimately high ITS on the job (Stamper \& Van Dyne, 2003:33). Various theories have been developed to authenticate the above assertion such as the relational exchange theory, affect theory, powerdependence theory, relational cohesion theory and leader member exchange (LMX) theory. In this study, social exchange theory (SET) provides the theoretical ground for LMX theory, which were used because of their relevance to the current study in that OCB leads to employees opting to stay on the job and reduces turnover intention. Therefore, based on the aforementioned theoretical reasoning and empirical evidence, it is posited that:

H3: Organisational citizenship behaviour has a significant positive effect on intention to stay on the job in Zimbabwe SME sector.

Relationship between employee perception of equity and employee intention to stay: A cross analysis of the existing empirical human resources literature indicates that EPE leads to low turnover intention (Ranida 2005). The reasoning is that when employees feel well treated, they feel motivated to stay in an organisation, therefore, it reduces their intention to leave and the opt to stay with the company (Fishbein \& Ajzen 1975; Griffeth, Hom \& Greater, 2000; Price, 2001). The reasoning in equity theory as well as justice judgment theory also supports this argument. Consequently, when SME employees perceive equity in their 
organisation, they are happy and become loyal to that organisation. Finally, the employees would not opt for leaving the job (Currivan, 1999; Solinger, Olffen \& Roe, 2008). In such a case, they are motivated to leave the organisation; hence, their turnover intention is reduced. Therefore, this research postulates that:

H4: Employees' perceptions of equity have a significant strong positive effect on their intention to stay in the Zimbabwe SME sector.

Relationship between organisational commitment and employee intention to stay: The relationship between OC and ITS has been revised and scrutinised extensively by researchers and academics (Meyer \& Allen 1997; Cater \& Zabkar (2009). Most of these studies argue that OC is an indication of employee satisfaction with their workplace and as a result of this satisfaction, their turnover intention is reduced. Besides, equity and justice judgment theories agree in that an employee who feels fairly treated, motivated and committed to the job is unlikely to contemplate leaving an organisation for another organisation. Furthermore, substantial empirical evidence has supported the positive linkage between OC and employee ITS on the job (Meyer \& Allen, 1991; Meyer \& Herscovitch, 2001; Rhoades, Eisenberger \& Armeli, 2001; Meyer, Stanley, Herscovitch \& Topolynytsky, 2002). Hence, when workers are committed to their organisation because they feel motivated and fairly treated, they are inspired to stay on the job. Therefore, drawing from the aforementioned arguments, it is posited that:

H5: Employees' organisational commitment has a strong significant positive effect on their intention to stay in the Zimbabwe SME sector.

\section{Methodology}

Sampling design technique: There are two types of sampling designs, which is probability and nonprobability sampling techniques. The study made use of a probability sampling method. With stratified sampling, the population was divided into mutually exclusive groups (industry sectors) and random samples were drawn from each group (Hair, Babin, Anderson \& Tatham, 2010). This procedure placed the SMEs into specific industry sectors (manufacturing and service).

Target Population: The database of the Ministry of Small and Medium Enterprises was used to collect information from employees in non-managerial positions in SMEs in Zimbabwe. The sample was drawn from the major cities in Zimbabwe (Chitungwiza, Bulawayo, Bindura, Chinhoyi and Harare). Non-managerial employees provided the information that was needed in this study because they are paid least and have many grievances in comparison with those who are in managerial positions, who tend to be secretive, happy and are highly remunerated (Gono, 2009). 275 SMEs were surveyed. Out of 275, 224 usable questionnaires were returned yielding a valid response rate of 81 percent.

Measurement Instruments: Research scales were operationalised mainly based on previous work. Minor adaptations were made in order to fit the current research context and purpose. Seven-item scales, which were adapted from the previous works of Jung and Yoon (2012) were used to measure OCB. Six questions were adapted from Janssen (2001) to measure employee EPE. A nine-item scale adapted from Powell and Meyer (2004) was utilised to determine OC. A five-item scale was adapted from Wayne, Shore and Liden (1997) to measure employee ITS on the job. All the measurement items were measured on a seven-point Likert-type scale that was anchored by $1=$ strongly disagree to $7=$ strongly agree, to express the degree of agreement.

Results of Tests of Measures and Accuracy Analysis Statistics: Statistical Package for Social Sciences (SPSS) 22.0 and AMOS 22.0 were used to carry out the statistical analysis. Confirmatory factor analysis (CFA) was performed to examine the reliability and convergent and discriminant validity of the multi-item construct measures. All the factor loadings are above 0.5 , which shows a high validity of the measurement instruments used. Overall acceptable CFA model fit indices used in this study included the $\chi^{2} /(\mathrm{df})$ (chisquare/degree of freedom) value equal to or less than 3.00, the CFI (comparative fit index) value equal to or higher than 0.90, Tucker and Lewis index (TLI) value equal to or higher than 0.90 , the incremental index of fit (IFI) value equal to or higher than 0.90 and the root mean square error of approximation (RMSEA) value equal to or less than 0.08. Recommended statistics for the final overall model assessment showed an acceptable fit of the measurement model to the data, namely $\chi^{2} /(\mathrm{df})=2.69 ; \mathrm{GFI}=0.91 ; \mathrm{AGFI}=0.86$; CFI $=0.98$; $\mathrm{TLI}=0.97 ; \mathrm{TLI}=0.97$ and RMSEA $=0.061$. 
Reliability and Validity: Cronbachth alpha test (Cronbach $\alpha$ ), composite reliability test (CR) and average value extracted (AVE) test were used in the study to check the reliability of the research measures. Table 1 shows the results of these three tests.

Table 1: Accuracy analysis statistics

\begin{tabular}{|c|c|c|c|c|c|}
\hline $\begin{array}{l}\text { Research } \\
\text { constructs }\end{array}$ & $\begin{array}{l}\text { Cronbach's } \\
\text { Item-total }\end{array}$ & $\begin{array}{l}\text { test } \\
\alpha \text { Value }\end{array}$ & C.R. & AVE & Factor loading \\
\hline OCB-1 & 0.919 & \multirow{5}{*}{0.985} & \multirow{5}{*}{0.985} & \multirow{5}{*}{0.822} & 0.927 \\
\hline OCB-2 & 0.932 & & & & 0.943 \\
\hline OCB-3 & 0.922 & & & & 0.937 \\
\hline OCB-4 & 0.933 & & & & 0.945 \\
\hline OCB-5 & 0.915 & & & & 0.928 \\
\hline EPE-1 & 0.940 & \multirow{7}{*}{0.989} & \multirow{7}{*}{0.990} & \multirow{7}{*}{0.831} & 0.942 \\
\hline EPE-2 & 0.935 & & & & 0.938 \\
\hline EPE-3 & 0.910 & & & & 0.919 \\
\hline EPE-4 & 0.926 & & & & 0.941 \\
\hline EPE-5 & 0.918 & & & & 0.939 \\
\hline EPE-6 & 0.947 & & & & 0.949 \\
\hline OC-1 & 0.907 & & & & 0.921 \\
\hline OC-2 & 0.920 & \multirow{8}{*}{0.991} & \multirow{8}{*}{0.992} & \multirow{7}{*}{0.837} & 0.941 \\
\hline OC-3 & 0.911 & & & & 0.952 \\
\hline OC-4 & 0.947 & & & & 0.962 \\
\hline OC-5 & 0.935 & & & & 0.947 \\
\hline OC- 6 & 0.925 & & & & 0.959 \\
\hline OC-7 & 0.947 & & & & 0.968 \\
\hline OC-8 & 0.936 & & & & 0.948 \\
\hline OC-9 & 0.929 & & & \multirow{6}{*}{0.804} & 0.950 \\
\hline ITS-1 & 0.970 & \multirow{5}{*}{0.966} & \multirow{5}{*}{0.966} & & 0.977 \\
\hline ITS-2 & 0.970 & & & & 0.977 \\
\hline ITS-3 & 0.945 & & & & 0.959 \\
\hline ITS-4 & 0.953 & & & & 0.964 \\
\hline ITS-5 & 0.968 & & & & 0.976 \\
\hline
\end{tabular}

Note: OCB=Organisational citizenship behaviour, EPE=Employee perception of equity, OC=Organisational commitment, ITS=Employee intention to stay C.R.=Composite reliability; AVE=Average variance extracted; $S . V=$ Shared variance; ${ }^{*}$ significance level $\mathrm{p}<0.05 ;{ }^{* *}$ significance level $\mathrm{p}<0.01 ;{ }^{* * *}$ significance level $\mathrm{p}<0.001$ Measurement CFA model fits: $\chi^{2} /(d f)=2.69, G F I=0.91, A G F I=0.86, C F I=0.98, T L I=0.97$ and $R M S E A=0,061$.

The internal reliability of each construct was measured using the standardised Cronbach coefficient alpha. A higher level of Cronbach's coefficient alpha demonstrated a higher reliability of the scale. The results of scale reliability tests are shown in Table 1. Further, the item-to-total correlation values ranged from 0.939 to 0.980 , which were above the cut-off point of 0.5 as recommended by Anderson and Gerbing (1988). A Cronbach alpha value that is equal to or greater than 0.7 indicates satisfactory reliability (Blunch, 2008). Table 1 indicates that the Cronbach alpha coefficients ranged from 0.983 to 0.993 . The reliability of each construct also was evaluated using the composite reliability (CR) index test. According to the literature, a composite reliability index that is greater than 0.7 depicts an adequate internal consistency of the construct (Hair, Anderson, Tatham \& Black, 2006). The results in Table 1 indicate that CR indexes were between 0.983 and 0.993 . The CR indexes range from 0.979 to 0.992 . These values exceeded the estimate criteria used by the previous literature (Hair et al., 2010); thus, affirming satisfactory composite reliability.

In this study, the average variance extracted estimate reflected that the overall amount of variance in the indicators was accounted for by the latent construct. Higher values for the variance extracted estimate (greater than 0.40 ) revealed that the indicators represented the latent construct. Overall, all average variance explained (AVE) values were above 0.5 (refer to Table 1), thus accepted according to the literature (Fraering \& Minor, 2006). Discriminant validity of the research constructs was evaluated on the basis of whether the correlations among latent constructs were less than or equal to 0.6 (Sin, Tse, Heung \& Yim, 2005). In Table 2, 
the inter-correlation values for all paired latent variables are less than or equal to 0.6 , therefore, indicating the existence of discriminant validity. The correlation values of $\mathrm{OCB}$ and $\mathrm{EPE}=0.600 ; \mathrm{OC}$ and $\mathrm{OCB}=0.572 ; \mathrm{OC}$ and $\mathrm{EPE}=0.586$, ITS and $\mathrm{OCB}=0.558$, ITS and $\mathrm{EPE}=0.543$ and ITS and OC $=0.592$ were less than 0.6 or equal to 0.6, which is within the recommended threshold (Bryman \& Bell, 2007), thus affirming discriminant validity.

Table 2: Correlations Matrix Table

\begin{tabular}{lllll}
\hline RESEARCH CONSTRUCT & OCB & EPE & OC & ITS \\
\hline OCB & 1.000 & & & \\
EPE & 0.580 & 1.000 & & \\
OC & 0.562 & 0.576 & 1.000 & \\
ITS & 0.550 & 0.541 & 0.569 & 1.000 \\
\hline
\end{tabular}

OCB=Organisational citizenship behaviour, EPE=Employee perception of equity, OC=Organisational commitment, ITS=Employee intention to stay

Therefore, discriminant validity further was established by checking if the AVE value was greater than the highest shared variance (SV) value (Sin et al., 2005).The average variance extracted (AVE) and the SV values were examined. Discriminant validity was established by checking and confirming that the AVE values were greater than the highest SV values (Nunnally, 1998). Table 2 affirms that all the AVE values are above the SV values for the research constructs; therefore, further confirming the existence of discriminant validity. An acceptable CFA measurement model fit was obtained, the study then proceeded to the hypothesis testing stage using structural equation modeling with AMOS 22.0 software programme. Recommended statistics for the final overall-model assessment showed acceptable fit of the measurement model to the data. The ratio of chi-square over degree-of-freedom was 2.80. This value is less than the recommended threshold of less than 3.0, therefore, confirms the model fit. Additionally, GFI, AGFI, CFI, TLI and RMSEA values were 0.89; 0.88; 0.96; 0.98 and 0.060 respectively. All these model fit measures were above recommended accepted threshold value of greater than 0.8 for GFI, AGFI, CFI, TLI and less than 0.8 for RMSEA (Anderson \& Gerbing, 1988), which suggested that the proposed conceptual model converged well and could be a plausible representation of the underlying empirical data structure collected in Zimbabwe. Since the model fit is acceptable, the study proceeded to test the research hypotheses. The equivalent coefficients of the research hypotheses that posited the existence of positive relationships between the variables and outcome consequences then were obtained.

Figure 2: Path modelling and factor loading results

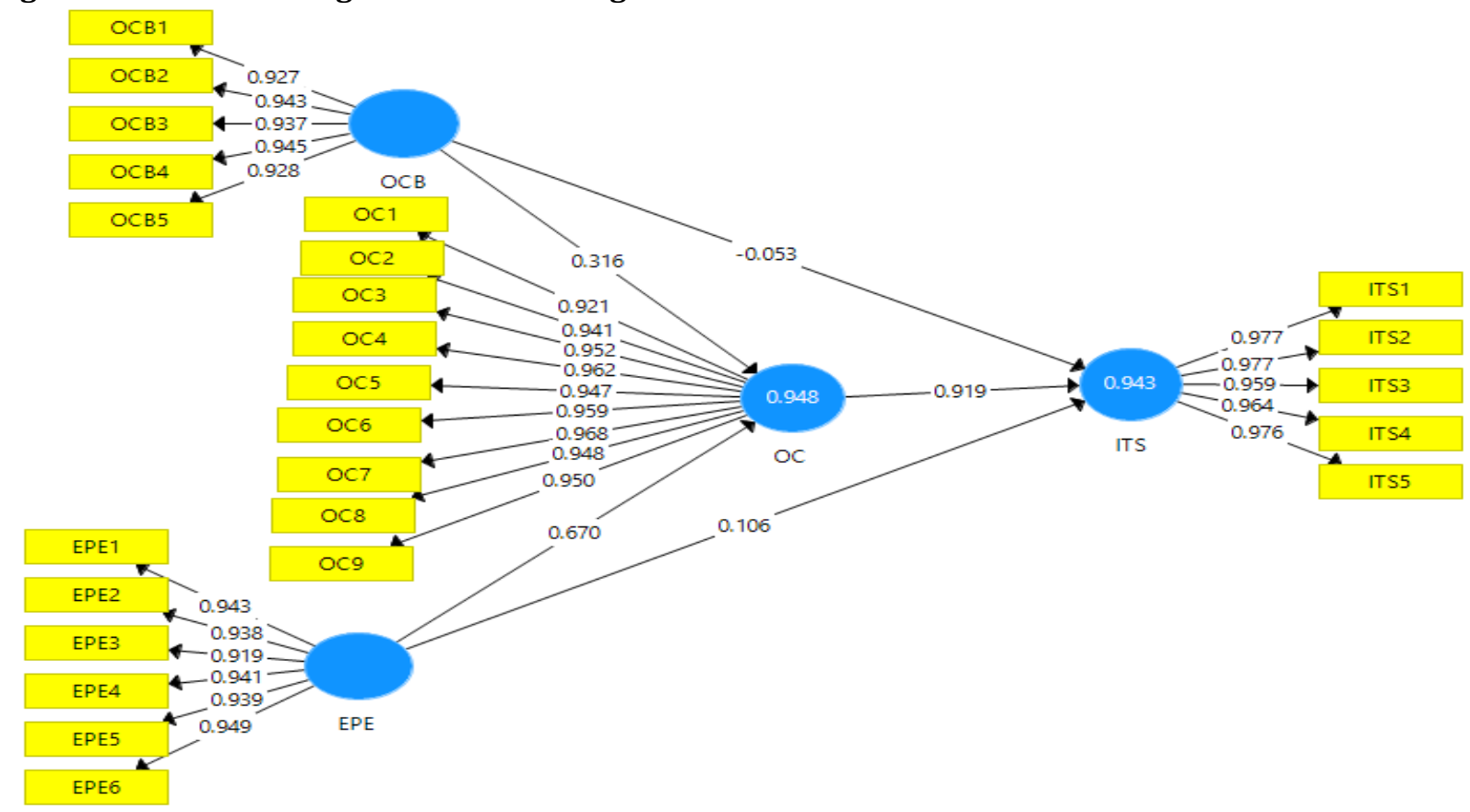


Path modelling results: The study proceeded to test the proposed hypotheses. In total, there are five hypotheses that are tested. In the path model, OCB and EPE are the independent variables, OC is the mediator and ITS is the outcome/dependent variable. Figure 2 provides the proposed hypotheses and the respective path coefficients. The same results of the path coefficients are tabulated in Table 1 depicting the item to total correlations, average variance extracted (AVE), composite reliability (CR) and factor loadings.

Path modelling and factor loadings: Figure 2 indicates the path modelling results and as well as the item loadings for the research constructs. In the figure, OCB stands for organisational citizenship behaviour; EPE is the abbreviation for employee perception of equity; OC stands for OC and ITS stands for employee intention to stay.

Table 3: Results of path modelling analysis

\begin{tabular}{lllll}
\hline Hypothesis statement & Hypothesis & Path coefficient & T-Statistics & Results \\
\hline OCB $\rightarrow$ Organisational commitment & H1 & $0.316^{* * *}$ & 5.656 & Supported \\
EPE $\rightarrow$ Organisational commitment & H2 & $0.670^{* * *}$ & 10.099 & Supported \\
OCB $\rightarrow$ Employee intention to stay & H3 & $0.053^{* * *}$ & 2.033 & Supported \\
EPE $\rightarrow$ Employee intention to stay & H4 & $0.106^{* * *}$ & 2.675 & Supported \\
OC $\rightarrow$ Employee intention to stay & H5 & $0.919^{* * *}$ & 25.098 & Supported \\
\hline
\end{tabular}

Structural model fits: $\chi^{2} / \mathrm{df}=2.80$; GFI=0.89; AGFI=0.88; CFI=0.96; TLI=0.98; RMSEA=0.060. Note: $1 .{ }^{* * *} p$ value $<0.001,{ }^{* *} p$-value $<0.05,{ }^{*} p$-value $<0.1$; using a significance level of 0.05 , critical ratios ( $t$-value) that exceed 1.96 would be called significant.2. The parameter compared by others is set as 1, therefore, no C.R. It is determined as significant.

As can be deduced from Table 3, all the hypotheses are significant and strong because all the path coefficients are greater than 0.5. The highest path coefficient is EPE and OC, which is 0.958, showing statistical significance indicating that in organisations where employees perceptions of equity is high, OC is also high (Almar 2005). The lowest path coefficient is OCB and OC, which is 0.819 slightly lower than the highest path coefficient. This shows that all the path coefficients are significant. In Table 3, the standardised coefficient values of these variables are used when explaining the relationship between independent and dependent variables. The higher the standardised coefficient value, the greater the effect the independent variables have on dependent variables. The critical ratio (CR) values, which represent the t-value, must be higher than 1.96. In this model, all the variables meet this requirement because they are greater than 1.96. The $\mathrm{p}$-values are all less than 0.001 , which shows a strong relationship between the variables, therefore, all five hypotheses were supported.

Discussion of the Results: There is a significant positive impact of employee OCB on OC in Zimbabwean SMEs. From the result of the path, there is a strong relationship between these two constructs ( $p$-value $<0.001)$.It can be observed in Figure 1 and Table 3 that perceived OCB exerted a positive influence $(r=0.316)$ and was statistically significant $(t=5.656)$ in predicting OC. Robbins and Judge (2011) emphasised that successful organisations need employees who will do more than their usual job duties and who will provide performance beyond expectations, which ultimately leads to OC. Such innovative and spontaneous behaviours by employees can contribute greatly to the cooperation and performance of the SMEs (Yoon \& Suh, 2003; Yildrim et al., 2012). Therefore, high OCB is associated with high OC. Hypothesis 2, posited that there is a significant strong positive influence of EPE on OC ( $p$-value $<0.001$ ). This hypothesis was supported in this study. Figure 1 and Table 3, indicate that perceived EPE, H2 was supported. Perceived EPE exerted a positive influence $(r=0.670)$ on $\mathrm{OC}$ and was statistically significant $(\mathrm{t}=10.098)$. Research consistently finds that people care about fair treatment and when individuals perceive that they are treated fairly, they express greater satisfaction with social relationships and consequently greater commitment (Park et al., 2010; Nicklin et al., 2011; Robbins \& Judge, 2011). Therefore, the greater the EPE, the greater the OC in return. As for hypothesis 3, there is a significant positive relationship between employees OCBs and their ITS in Zimbabwe's SME sector. The path p-value shows there is a significant relationship between these two factors (p-value < 0.001).It is reported in Figure 1 and Table 3 that H3 perceived OCB exerts a positive $(r=0.053)$ influence on ITS and that this influence is statistically significant $(\mathrm{t}=2.033)$. Evidence indicates that organisations that have such employees with strong OCB outperform those that do not have such employees (Greenberg, 2009; Jain \& Cooper, 2012; Jung \& Yoon, 2012). Managers need to reduce absenteeism, turnover 
and deviant workplace behaviours and instil a strong sense of OCB. In this way, employees, in the long run, will feel wanted and a part of the organisation and will opt for staying in an organisation.

The fourth hypothesis posited that there is a strong positive significant relationship of EPE with employee ITS (p-value $<0.001$ ). As can be deducted from Figure 1and Table 3, EPE exerted a positive and significant influence $(r=0.106 ; \mathrm{t}=2.675)$ on ITS. This result depicts that EPE is associated with higher ITS. It is argued further that perceived inequities at the workplace also impact negatively on job performance (Park et al., 2010), cooperation with co-workers (Kanopaske \& Werner, 2002) and work quality (Cardy, Miller \& Ellis, 2007). The last hypothesis, which is 5 , posited that there is a strong positive relationship between OC and ITS in Zimbabwean SMEs (p-value < 0.001). It is reported in Figure 1 and Table 3 that H5 perceived OC exerts a positive ( $r=0.919)$ influence on ITS and that this influence is statistically significant $(\mathrm{t}=25.098)$. Low levels of OC may be dysfunctional to both the organisation and the individual, while high levels may have positive effects that lead to higher performance, greater satisfaction and low turnover (Currivan, 1999). Drawing from the extant literature it is noted that, by and large, committed individuals believe in and accept organisational goals and values. This means that the individuals will be willing to remain with their organisations and provide considerable effort towards the achievement of their organisation's goals (Mowaday et al., 1979; Cater \& Zabka, 2009). Perceived OC ( $r=0.919)$ emerged as the highest scoring construct amongst the three factors influencing ITS. Perhaps, this result could be attributed to the fact that most employees do not want to leave organisations in which they are committed to. A study by Currivan (1999) affirms that OC leads to employees' ITS on the job. In summary, the results show that the five hypotheses are supported in the entire model as hypothesised.

\section{Conclusion and Recommendations}

Recommendations to SMEs Managers and Government: The paper provides both theoretical and practical contributions. This is the first paper to the best knowledge of the researcher that applied the Social Identity Theory (SIT) in organisational behaviour literature; which means the theory added new knowledge to the existing literature on organisational behaviour. The paper has practical contribution to managers or owner of SMEs to practice good management relations to have greater OCBs, EPE, OC and ITS in SMEs organisations. It is recommended that policy makers and academics assist SME owners/managers through free education and entrepreneurial programs that will equip them to draft plans and strategic policies to position themselves for competitive advantage in the business world. Owners/managers of SMEs seeking to improve their performance, therefore, constantly need to monitor and evaluate the progress in goal achievement. This will help them to address problems in strategy implementation and to raise employee morale because employees achieve gratification if the set goals are achieved. To secure increased employee motivation levels, SMEs need to make use of more diversified incentives that could include salary raises, promotions, titles, trophies, holiday assistance, and house and car purchase assistance. The owners/managers also need to inform and involve many employees in the decision-making process, as their participation leads to motivation and, hence, commitment to goal achievement. A more participative process will ensure cooperation and positive relationships among employees, therefore, leading to OC and, ultimately, reducing turnover intention (Cardy et al., 2007). The results of this study are likely to benefit the government of Zimbabwe at large. The government of Zimbabwe is also encouraged to help SMEs, which are in financial difficulty as their survival contributes to employment and the country's GDP. Based on the current study findings, trade unions in the SME sector also are encouraged to represent their members' grievances with their employers and the government. Finally, the government of Zimbabwe is encouraged to adopt policies that are likely to provide a stable socio-economic stability in the country such that the SMEs may improve their performance.

Limitations and Propositions for Future Research: Significant contributions were singled out in this study. Even though due care was taken to achieve thoroughness, there are some limitations, which open up avenues for further research. Subsequent research could replicate this study in broader sampling contexts that include all the SMEs in Zimbabwean cities or a comparative analysis between Zimbabwe and another country such as South Africa, Malawi and Tanzania. The other limitation is that the data were cross-sectional, which makes it difficult to generalise the findings, unlike longitudinal data. Looking on the other side of the coin, future research efforts should investigate outcomes of OCB and EPE such as job satisfaction, workplace spirituality and organisational support. The proposed model is a mediation model. In other words, OC mediates the 
relationship between OCB and ITS; and OC mediates the relationship between EPE and ITS. However, these were not discussed in the study. There needs to be hypotheses focusing on the mediation. Future research might test the mediation using regression analysis. In research there is no best theory, which is applicable to any study. Future research should try to include other theories for this same model such as justice judgment theory and social exchange theory in order to evaluate the outcomes. Another implication is that future work should consider the role of time. Indeed OCBs, OC and employee EPE changes over time. Comprehensive understanding of these behaviours could be obtained over time. Extending this type of research through longitudinal studies that capture patterns or changes in OCBs over days, weeks, months or years would provide insight into the emergence and variation of OCB in the presence of different interpersonal and contextual factors. Longitudinal data would likely enable a more accurate assessment of the interactive effects of OCB, employee EPE, OC and employee ITS.

Conclusion: This paper sought to investigate the influence of EPE and OCB on employee OC and employee ITS. The equity theory was used to explain the relationships between the four variables in which employee ITS is the ultimate variable. Structural equation modelling was used to analyse the data using Amos 22.0. The study showed that there is a positive relationship between all five hypotheses. The results of this study show that there is a strong positive relationship between OCB, EPE, OC and, ultimately, employee ITS. Therefore, it means that the more SMEs increase their equity perceptions, OCBs and OC, the more the employee will be satisfied and decide to remain in the employment.

\section{References}

Abrams, D., Hogg, M. A., Hinkle, S. \& Otten, S. (2005). The social identity perspective on small groups. In Poole M.S. \& Hollingshead A.B., eds. Theories of small groups: interdisciplinary perspectives. Thousand Oaks, CA: SAGE. pp. 99-137

Allen, N. J. \& Meyer, J. P. (1990). The measurement and antecedents of affective, continuance and normative commitment to the organisation. Journal of Occupational Psychology, 63, 1-18.

Almar, M. W. (2005). Equity sensitivity and negotiation behaviors: a look at Mexican exporters. Academy of Management Journal, 4(3), 1-16.

Anderson, J. C. \& Gerbing, D. W. (1988). Structural equation modelling in practice: a review and recommended two-step approach. Psychological Bulletin, 103(3), 411-423.

Andrews, M. C., Witt, L. A. \& Kacmar, K. M. (2003). The interactive effects of organisational politics and exchange ideology on manager ratings of retention. Journal of Vocational Behavior, 62(2), 357-369.

Ashforth, B. E. \& Mael, F. (1989). Social identity theory and the organisation. Academy of Management Review, 14, 20-39.

Balsam, S. \& Miharjo, S. (2007). The effect of equity compensation on voluntary executive turnover. Journal of Accounting and Economics, 43, 95-119.

Bateman, T. S. \& Organ, D. W. (1983). Job satisfaction and the good soldier: the relationship between affect and employee 'citizenship. Academy of Management Journal, 26, 587-595.

Becker, T. E. (1992). Foci and bases of commitment: Are they distinctions worth making? Academy of Management Journal, 35, 232-244.

Biggs, T. \& Shah, M. K. (2006). African SMEs, networks and manufacturing performance. Journal of Banking and Finance, 30(11), 3043-3066.

Blunch, N. J. (2008). Introduction to structural equation modeling using SPSS and AMOS. Singapore: McGrawHill.

Bolino, M. C. \& Turnley, W. H. (2005). The personal costs of citizenship behavior: the relationship between individual initiative and role overload, job stress, and work-family conflict. Journal of Applied Psychology, 90, 740-748.

Brown, J. (2000). Employee turnover costs billions annually. IT Training \& Careers. http://www.accessmylibrary.com/coms2/summary 0286-28703700 ITM.

Bryman, A. \& Bell, E. (2007). Business Research Methods. $2^{\text {nd }}$ ed. Oxford: University Press.

Cardy, R. L., Miller, J. S. \& Ellis, A. D. (2007). Employee equity: toward a person-based approach to HRM. Human Resource Management Review, 17, 140-151.

Carson, D. \& Gilmore, A. (2000). Marketing at the interface: Not "What" but "How". Journal of Marketing Theory and Practice, 30(5), 122-133. 
Carmon, A. F., Miller, A. N., Raile, A. N. W. \& Roers, M. M. (2010). Fusing family and firm: employee perceptions of perceived homophily, organisational justice, organisational identification, and organisational commitment in family businesses. Family Business Strategy, 1, 210-223.

Cater, B. \& Zabkar, V. (2009). Antecedents and consequences of commitment in marketing research services: the client's perspective. Industrial Marketing Management, 38(7), 785-797.

Carmeli, A., Gilat, G. \& Waldman, D.A. (2007). The role of perceived organisational performance in organisational identification, adjustment and job performance. Journal of Management Studies, 44, 972-992.

Chiang, C. F. \& Hsieh, T. S. (2011). The impacts of perceived organisational support and psychological empowerment on job performance: The mediating effects of OCB. International Journal of Hospitality Management, 31(1), 180-189.

Cheney, G. (1983). Organisational identification as process and product: a field study. Unpublished master's thesis. Indiana: Purdue University Press.

Chinomona, R., Lin, J., Wang, M. \& Cheng, J. (2010). Soft power and Desirable Relationship Outcomes in Zimbabwe Distribution Channels. Journal of African Business, 11(2), 182-200.

Chinomona, R. \& Pretorius, M. (2011). SME manufacturers cooperation and Dependency on major dealers. Expert power in Distribution Channels. South African Journal of Economics and Management Sciences, $14(2), 170-187$.

Chinomona, R. (2012). The impact of organizational support on work spirituality, organizational citizenship behavior and job performance: The case of Zimbabwe's small and medium enterprise (SME) sector. African Journal of Business Management, 6(36), 10003-10014.

Chinomona, E. \& Dhurup, M. (2016). The effects of organizational commitment and employee perceptions of equity on organizational citizenship behavior in Zimbabwean SMEs. South African Journal of Labor Relations, 40(20), 1-22.

Chinomona, E. (2016). Organizational citizenship behavior and employee perception of equity on organizational commitment. Corporate Ownership and Control, 14(1), 230-240.

Chinomona, E. \& Dhurup, M. (2015). The role of organizational commitment in the organizational citizenship behavior and employee intention to stay relationship: The case of Zimbabwe. International Journal of Humanities and Social Science, 5(7), 47-58.

Chipika, S. \& Wilson, G. (2006). Enabling Technology learning among light engineering SMEs in Zimbabwe through networking. Journal of Technovation, 26(8), 969-979.

Cho, S. \& Johanson, M. M. (2008). Organisational citizenship behavior and employee performance: A moderating effect of work status in restaurant employees. Journal of Hospitality and Tourism Research, 32, 307-326.

Cohen-Charash, Y. \& Spector, P. E. (2001). The role of justice in organisations: A meta-analysis. Organisational Behaviour and Human Decision Processes, 86, 278-324.

Colquitt, J. A., Conlon, D. E., Wesson, M. J., Porter, C. O. \& Ng, K. Y. (2001). Justice at the millennium: A metaanalytic review of 25 years of organisational justice research. Journal of Applied Psychology, 86(3), 425-445.

Cropanzano, R., Howes, J. C., Grandey, A. A. \& Toth, P. (1997). The relationship of organisational politics and support to work behaviors, attitudes and stress. Journal of Organisational Behaviour, 18,159-180.

Currivan, D. B. (1999). The causal order of job satisfaction and OC in models of employee turnover. Human Resource Management Review, 9(4), 495-524.

De Cremer, D., Van Dijke, M. H. \& Mayer, D. (2010). Cooperating when "you" and "I" are treated fairly: The moderating role of leader prototypicality. Journal of Applied Psychology, 95, 1121-1133.

Dukerich, J. M., Kramer, R. \& Parks, J. M. (1998). The dark side of organisational identification. In Whetton D.A. \& Godfrey P.C. eds. Identity in organisations: building theory through conversations. Thousand Oaks, CA: SAGE. pp. 245-256.

Egan, M. T., Yang, B. \& Barlett, R. K. (2004). The effect of organisational learning culture and job satisfaction on motivation to transfer learning and turnover intention. Human Resource Development Quarterly, 15(3), 90-117.

Ferris, G. R., Adams, G., Kolodinsky, R. W., Hochwarter, W. A. \& Ammeter, A. P. (2002). Peceptions of organisational politics: Theory and research indications. In Miller, Brian, K., Matthew, A. and Kolodinsky, R.W. 2008 (Eds). Perceptions of organisational politics: a meta-analysis of outcomes. (pp.209-222). Journal of Business Psychology, 22, 209-222. 
Fields, D. (2002). Taking the Measure of Work: A Guide to Validated Scales for Organisational Research and Diagnosis. Thousand Oaks, CA: SAGE.

Fishbein, M. \& Ajzen, I. (1975). Belief, Attitude, Intention and Behavior: An Introduction to Theory and Research: London:Addison Wesley.

Fraering, M. \& Minor, M. S. (2006). Sense of Community: An Exploratory Study of US Consumers of Financial Services. International Journal of Bank Marketing, 24(5), 284-306.

Gautam, T., Van Dick, R. \& Wagner, U. (2004). Organisational identification and organisational commitment: Distinct aspects of two related concepts. Asian Journal of Social Psychology, 7, 301-315.

Ghapanchi, A. H. \& Aurum, A. (2011). Antecedents to IT personnel's intentions to leave: A systematic literature review. The Journal of Systems and Software, 84, 238-249.

Gono, G. (2009). Zimbabwe's Casino Economy. Extraordinary measures for extraordinary Challenges. Zimbabwe Publishing House, Harare.

Greenberg, J. (2009). Everybody talks about organisational justice, but nobody does anything about it. Industrial and Organisational Psychology, 2, 181-195.

Griffeth, R. W., Hom, P. W. \& Gaertner, S. (2000). A meta-analysis of antecedents and correlates of employee turnover: update, moderator tests, and research implications for the next millennium. Journal of Management, 26(3), 463-488.

Hair, J. F., Anderson, R. E., Tatham, R. L. \& Black, W. C. (2006). Multivariate Data Analysis 6th ed. London: Prentice-Hall.

Hair, J. F., Babin, B. J., Anderson, R. E. \& Tatham, R. L. (2010). Multivariate Data Analysis. A Global Perspective

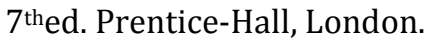

Hogg, M. A. \& Vaughn, G. M. (2002). Social Psychology. 3rd edition. London: Prentice Hall.

Hogg, M. A., Abrams, D., Otten, S. \& Hinkle, S. (2004). The social identity perspective: Intergroup relations, self-conception, and small groups. Small Group Research, 35, 246-276.

Hom, P. W. \& Griffeth, R. W. (1995). Employee Turnover. International Thompson Publishing. Ohio, USA.

Hwamiridza, M. 2007. SME bourse remains a dream. [On-line]. Available at: http://www.herald.co.zw/inside.aspx?sectid=29835\&cat=8. Date accessed 24/09/2007.

Jain, A. K. \& Cooper, C. L. (2012). Stress and OCBs in Indian business process outsourcing organisations. IIMB Management Review, 24, 155-163.

Janssen, O. (2001). Fairness perceptions as a moderator in the curvilinear relationships between job demands and job performance and job satisfaction. Academy of Management Journal, 44(5), 1039-1050.

Jones, D. A. \& Mcintosh, B. R. (2010). Organisational and occupational commitment in relation to bridge employment and retirement intentions. Journal of Vocational Behaviour, 77, 290-303.

Joseph, D., Kok-Yee, N., Koh, C. \& Ang, S. (2007). Turnover of information technology professionals: a narrative review, meta-analytic structural equation modeling and model development. MIS Quarterly, 31(3), 547-577.

Jung, H. S. \& Yoon, H. H. (2012). The effects of emotional intelligence on counterproductive work behaviours and organisational citizen behaviors among food and beverage employees in a deluxe hotel. International Journal of Hospitality Management, 31(2), 369-378.

Kanopaske, R. \& Werner, S. (2002). Equity in non-North American contexts: adapting equity theory to the new global business environment. Human Resource Management Review, 12, 405-418.

Kapoor, K., Mugwara, D. \& Chidavaenzi, I. (1997). Empowering Small Enterprises in Zimbabwe. World Bank Discussion Paper No, 379. Washington, D.C: The International Bank for Reconstruction.

Kinicki, A. \& Kreitner, R. (2008). Organisational Behaviour. Key concepts, skills and best practices. McGraw Hill, New York.

Kotabe, M., Dubinsky, A. \& Chae, U. L. (1992). Perceptions of organisational fairness: A cross national perspective. International Marketing Review, 9(2), 41-59.

Kwon, S. Y. \& Jang, S. C. (2012). Effects of compensation for service recovery: From the equity theory perspective. International Journal of Hospitality Management, 31, 1235-1243.

Laschinger, H. K. S., Shamian, J. \& Thomson, D. (2001). Impact of magnet hospital characteristics on nurses' perceptions of trust, burnout, quality of care and work satisfaction. Nursing Economics, 19, 209-219.

Lemons, M. A. \& Jones, A. (2001). Procedural justice in promotional decisions. Using perceptions of fairness to build employee commitment. Journal of Managerial Psychology, 16(4), 268-281.

Li, J., Xin, K. \& Pillutla, M. (2002). Multi-cultural leadership teams and organisational identification in international joint ventures. International Journal of Human Resource Management, 13, 320-337. 
Machipisa, L. (1998). Developing the Focused Entrepreneur. [On-line]. Available at: http://72.14.207.104/search?q=cache:UiMJ1N2HYJ.www.ipsnews.net/domainlogin.Date accessed $6 / 04 / 2006$.

Mael, F. \& Ashforth, B. E. (1992). Alumni and their alma mater: A partial test of the reformulated model of organisational identification. Journal of Organisational Behaviour, 13, 103-123.

McKnight, D. H., Phillips, B. \& Hardgrave, B. C. (2008). Which reduces IT turnover intention the most workplace characteristics or job characteristics? Information \& Management, 46(3), 167-174.

Meyer, J. P. \& Allen, N. J. (1997). Commitment in the workplace. Thousand Oaks, CA: Sage.

Meyer, J. P. \& Allen, N. J. (1991). A three-component conceptualization of organisational commitment. Human Resource Management Review, 1, 61-68.

Meyer, J. P. \& Herscovitch, L. (2001). Commitment in the workplace: toward a general model. Human Resource Management Review, 11, 299-326.

Meyer, J. P., Stanley, D. J., Herscovitch, L. \& Topolnytsky, L. (2002). Affective, continuance, and normative commitment to the organisation: a meta-analysis of antecedents, correlates, and consequences. Journal of Vocational Behaviour, 61, 20-52.

Milliman, J., Czaplewski, A. J. \& Ferguson J. (2003). Workplace spirituality and employee work attitudes: an exploratory empirical assessment. Journal of Organisational Management, 16, 426-447.

Ministry of Small and Medium Enterprise Development in Zimbabwe. (2002). Small, Micro and Medium Enterprises (SMMEs). The Engine for Growth. Republic of Zimbabwe: Zimbabwe Publishing House.

Morrow, P. C., Macelroy, J. C. \& Scheibe, K. V. (2012). Influencing organisational commitment through office redesign. Journal of Vocational Behaviour, 81, 99-111.

Mitchell, T. R., Holtom, B. H., Lee, T. W., Sablynski, C. J. \& Erez, M. (2001). Why People Stay: Using Job Embeddedness to Predict Voluntary Turnover. The Academy of Management Journal, 44(6), 11021121.

Mowday, R. T., Porter, L. W. \& Steers, R. M. (1979). The measurement of organisational commitment. Journal of Vocational Behavior, 14, 224-227.

Moxley, R. (2000). Leadership Spirit. San Francisco: Jossey-Bass.

Mustapha, N., Ahamad, A., Uli, J. \& Idris, M. (2010). Job characteristics as antecedents of intention to stay and mediating effects of work family facilitation and family satisfaction among single mothers in Malaysia. International Journal of Business and Social Science, 1(3), 59-74.

N'Goala, G. (2007). Customer Switching Resistance (CSR); The effects of perceived equity, trust and relationship commitment. International Journal of Service Industry, 18(5), 510-524.

Nicklin, J. M., Greenbaum, R., Mcnall, L. A., Folger, R. \& Williams, K. J. (2011). The importance of contextual variables when judging fairness: an examination of counter factual thoughts and fairness theory. Organisational Behavior and Human Decision Processes, 11(2), 127-141.

Nunnally, J. C. (1998). Psychometric Theory. 2nd ed. New York: McGraw-Hill.

Nyoni, S. (2002). Small, Micro \& Medium Enterprises (SMMEs). Policy \& Strategy Framework. Harare: Zimbabwe Publishing House.

Organ, D. W. (1988). Organisational citizenship behavior: the good soldier syndrome. Lexington, MA: Lexington Books.

Organ, D. W. (1990). The motivational basis of organisational citizenship behavior. In Staw, B.M. \& Cummings L.L., eds. Research in Organisational Behaviour. $12^{\text {th }}$ ed. Greenwich, CT: JAI Press. pp. 43-72.

Park, J., Ellis, G. D., Kim, S. S. \& Prideaux, B. (2010). An investigation of perceptions of social equity and price acceptability judgments for campers in the U.S. national forest. Tourism Management, 31, 202-212.

Podsakoff, P. M., Ahearne, M. \& Mackenzie, S. B. (1997). Organisational citizenship behavior and the quantity and quality of work group performance. Journal of Applied Psychology, 82, 262-270.

Podsakoff, N. P., Whiting, S. W., Podsakoff, P. M. \& Blume, B. D. (2009). Individual- and organizational-level consequences of organizational citizenship behaviors: A meta-analysis. Journal of Applied Psychology, $94,122-141$.

Porter, L. W., Steers, R. M., Mowday, R. T. \& Boulian, P. V. (1974). Organisational commitment, job satisfaction and turnover among psychiatric technicians. Journal of Applied Psychology, 59, 603-609.

Powell, D. M. \& Meyer, J. P. (2004). Side-Bet theory and three-component model of OC. Journal of Vocational Behaviour, 65, 157-177. 
Pratt, M. G. (1998). To be or not to be? Central questions in organisational identification. In Whetton, D.A. \& Godfrey, P.C., eds. Identity in Organizations: Building Theory Through Conversations. Thousand Oaks, CA: SAGE. pp. 171-207.

Price, J. L. (2001). Reflections on the determinants of voluntary turnover. International Journal of Manpower, 22(7), 600-624.

Ranida, B. (2005). Perceptions of organisational politics and cooperation as moderators of the relationship between job strains and intent to turnover. Journal of Managerial Issues, 1(1), 1-30.

Ravichandran, S. \& Gilmore, S. A. (2007). Formation of OCBs in students employed in university Dinging services: impact of manager and co-worker behaviors. Journal of Foodservice Business Research, 10(2), 19-50.

Razali, M. Z. (2004). Perception of professional engineers towards quality of work life and organisational commitment. Gadjah Mada International Journal of Business, 6(3), 465-476.

Rego, A., Ribeiro, N., Cunha, M. P. \& Jesuino, J. C. (2011). How happiness mediates the organisational virtuousness and affective commitment relationship. Journal of Business Research, 64, 524-532.

Rhoades, L., Eisenberger, R. \& Armeli, S. (2001). Affective commitment to the organisation: The contribution of perceived organisational support. Journal of Applied Psychology, 86, 825-836.

Robbins, S. P. \& Judge, T. (2011). Organisational Behavior 14th ed. Prentice Hall, New Jersey.

Rosen, C. C., Chang, C. H., Johnson, R. E. \& Levy, P. E. (2009). Perceptions of the organisational context and psychological contract breach: Assessing competing perspectives. Organisational Behavior and Human Decision Process, 108(2), 202-217.

Rubin, R. S., Bommer, W. H. \& Bachrach, G. G. (2010). Operant leadership and employee citizenship: A question of trust? The Leadership Quarterly, 21, 400-408.

Ruyter, K. L., Moorman, J. \& Lemmink, J. (2001). Antecedents of Commitment and Trust in Customer-Supplier Relationships in High Technology Markets. Industrial Marketing Management, 30(3), 271-286.

Scott, C. R. (2007). Communication and Social Identity Theory: Existing and potential connections in organisational identification research. Communication Studies, 58, 123-138.

Shelley, P. (2001). Teachers' perceptions of gender equity in writing assessment. English Quarterly, 33(1), 2233.

Sieger, P., Bernhard, F. \& Frey, U. (2011), Affective commitment and job satisfaction among non-family employees: Investigating the roles of justice perceptions and psychological ownership. Journal of Family Business Strategy, 2, 78-89.

Sin, L. Y. M., Tse, A. C. B., Heung, V. C. S. \& Yim, F. H. K. (2005). An analysis of the Relationship between market orientation and business performance in the hotel industry. Hospitality Management, 24, 555-577.

Small Enterprise Development Corporation (SEDCO) of Zimbabwe. (2004). National Economic Consultative Forum. Report on the Policy Implementation Workshop For SMEs 25-27 October 2004.

Solinger, O. N., Olffen, W. V. \& Roe, R. A. (2008). Beyond the three component model of organisational commitment. Journal of Applied Psychology, 93(1), 70-83.

Stamper, C. L. \& Van Dyne L. (2003). Organisational citizenship: A comparison between part-time and fulltime service employees. Cornell Hotel and Restaurant Administration Quarterly, 44, 33-42.

Steinbeis, N. \& Singer, T. (2013). The effects of social comparison on social emotions and - behavior during childhood: The ontogeny of envy and Schadenfreude predicts developmental changes in equityrelated decisions. Journal of Experimental Child Psychology, doi: 10.1016/j.jecp.2012.11.009.

Tajfel, H. \& Turner, J. (1979). An integrative theory of intergroup conflict. In Austin W.G. \& Worschel, S., Eds. The social psychology of intergroup relations. Monterey, CA: Brooks/Cole. pp. 33-47.

Terry, D., Hogg, M. \& White, K. (1999). The theory of planned behaviour: Self-identity, social identity, and group norms. British Journal of Social Psychology, 38, 225-244.

Thatcher, J. B., Stepina, L. P. \& Boyle, R. J. (2003). Turnover of information technology workers: examining empirically the influence of attitudes, job characteristics, and external markets. Journal of Management Information Systems, 19(3), 231-261.

Thatcher, J. B., Liu, Y., Stepina, L. P., Goodman, J. M. \& Treadway, D. C. (2006). IT worker turnover: an empirical examination of intrinsic motivation. The Database for Advances in Information Systems, 37(2/3), 133146.

Tufail, M. S., Muneer, S. \& Ishtiaq, M. (2016). Job Characteristics with Task and Contextual Performance: Moderating Role of Procedural Justice for Front Line Managers. Journal of Social Sciences, Special Issue, 299-508 
Ucho, A., Mkavga, T. \& Onyishi, I. E. (2012). Job satisfaction, gender, tenure and turnover intentions among civil servants in Benue State. Interdisciplinary Journal of Contemporary Research in Business, 3(11), 378-387.

Van Dick, R., Christ, O., Stellmacher, J., Wagner, U., Ahlswede, O. \& Grubba, C. (2004). Should I stay or should I go? Explaining turnover intentions with organisational identification and job satisfaction. British Journal of Management, 15, 351-360.

Van Dyne, L. \& Lepine, J. A. (1998). Helping and voice extra-role behaviors: Evidence of construct and predictive validity. Academy of Management Journal, 41, 108-119.

Van Dijke, M., Cremer, D. D., Mayer, D. M. \& Quaquebeke, N. Y. (2012). When procedural fairness promote OCB? Integrating empowering leadership types in relational justice models. Organisational Behaviour and Human Decision processes, 117, 235-248.

Wayne, S. J., Shore, L. M. \& Liden, R. C. (1997). Perceived organizational support and leader-member exchange: A social exchange perspective. Academy of Management Journal, 40, 82-111.

Williams, L. J. \& Anderson, S. E. (1991). Job Satisfaction and organisational commitment as predictors of organisational citizenship and in-role behaviours. Journal of Management, 17(3), 601-617.

Yamaguchi, I. (2013). A Japan-US cross-cultural study of relationships among team autonomy, organisational social capital, job satisfaction, and OC. International Journal of Intercultural Relations, 37, 58-71.

Yildrim, Y., Uzum, H. \& Yildirim, I. (2012). An examination of physical education teachers in terms of their OCBs and organisational loyalty according to some demographic variables. Procedia-Social and behavioural Sciences, 47, 2146-2156.

Yoon, M. H. \& Suh, J. (2003). OCBs and service quality as external effectiveness of contact employees. Journal of Business Research, 56, 597-611. 